\title{
TDR measurement of stem and soil water content in two Mediterranean oak species
}

\author{
VIRGINIA HERNÁNDEZ-SANTANA ${ }^{1,2}$ \& JOSÉ MARTÍNEZ-FERNÁNDEZ ${ }^{1,2}$ \\ 1 Department of Geography, University of Salamanca, Cervantes 3, ES-37002 Salamanca, Spain \\ virhs@usal.es \\ 2 Centro Hispano Luso de Investigaciones Agrarias (CIALE), University of Salamanca, Rio Duero s/n, \\ ES 37185 Villamayor, Salamanca, Spain
}

\begin{abstract}
Since 1990s, time domain reflectometry (TDR) has been applied to estimate the stem water content of living trees. Here, new calibration equations relating the apparent dielectric constant $\left(K_{a}\right)$ to the volumetric water content $(\theta)$ were developed for two Mediterranean oak species. Our calibration equations differ from those previously calculated for other species, suggesting that stem water contents could be monitored more accurately using species-specific curves. The stem water content in the trees of these species and the surrounding soil were monitored with TDR to examine the feasibility of this technology for recording changes in trunk water storage. The average stem water contents of the oaks reflect the soil water contents, and the temporal differences observed $(17 \%)$ point to the importance of trunk water for coping with soil water deficit. Although it would be very useful to obtain a single function to estimate the stem water content of trees, it remains necessary to obtain the results in more species.
\end{abstract}

Key words Quercus pyrenaica; Quercus rotundifolia; stem water content; soil moisture; TDR

\section{Mesure par TDR des teneurs en eau du tronc et du sol pour deux espèces Méditerranéennes de chêne}

Résumé Depuis les années 1990, la réflectométrie en domaine temporel (TDR) a été appliquée pour estimer la teneur en eau du tronc d'arbres vivants. De nouvelles équations de calage reliant la constante diélectrique apparente $\left(K_{a}\right)$ à la teneur en eau volumique $(\theta)$ ont été développées pour deux espèces Méditerranéennes de chêne. Nos équations de calage diffèrent de celles qui ont été précédemment calculées pour d'autres espèces, suggérant que la teneur en eau du tronc pourrait être suivie plus précisément à l'aide de courbes spécifiques selon les espèces. Les teneurs en eau du tronc dans les arbres de ces espèces et dans le sol environnant ont été suivies par TDR afin d'étudier la faisabilité de cette technologie pour l'enregistrement des changements dans le stockage d'eau dans le tronc. Les teneurs en eau du tronc moyennes des chênes reflètent les teneurs en eau du sol, et les différences temporelles observées (17\%) montrent l'importance de l'eau du tronc pour compenser les déficits en eau du sol. Bien qu'il eût été très utile d'obtenir une fonction unique pour estimer la teneur en eau du tronc des arbres, il reste nécessaire d'obtenir des résultats avec un nombre plus important d'espèces.

Mots clefs Quercus pyrenaica; Quercus rotundifolia; teneur en eau du tronc; humidité du sol; TDR

\section{INTRODUCTION}

Trees link the soil to the atmosphere through the transpiration process, and one important issue in transpiration is water storage in tree stems (Waring \& Running, 1978). However, measuring the water content in standing trees remains a challenging task. The few tools that have been developed to measure water contents in living trees lack many of the attributes associated with recent electronic instrumentation (Constantz \& Murphy, 1990). In addition, stem water contents are difficult to determine because of tissue decay, high levels of hydration, and the geometric constraints of the trunk (Raschi et al., 1995).

Stem water content has been determined using a variety of methods, ranging from direct core sampling (Waring \& Running, 1978) to dendrometry (Braekke \& Kozlowski, 1975). Different approaches have been used to visualize the distribution of water in tree trunks such as gamma-ray attenuation (Edwards \& Jarvis, 1983; Brough et al., 1986), computer tomography (Raschi et al., 1995), and nuclear magnetic resonance (Byrne et al., 1986). There have also been some attempts to develop electronic techniques, such as frequency and time domain reflectometry (TDR). This latter method is widely used for the determination of soil water content. Soil moisture is determined by measuring the transit time of an electromagnetic pulse launched along a parallel metallic probe buried in the soil. It has been shown that the pulse travel time is proportional to the 
apparent dielectric constant of the soil: $K_{a}$ (Topp et al., 1980). The dielectric constant of free water $\left(K_{\text {water }}=80\right)$ is much greater than that of air $\left(K_{\text {air }}=1\right)$ or soil material $\left(3 \leq K_{\text {soil }} \leq 7\right)$. The main advantages of this technology are that it is highly accurate, it can be automated, it provides simple measurements, and it is soil texture-, porosity-, temperature- and salinity-independent (Topp et al., 1980). For different types of soils, Topp et al. (1980) found a relationship between the water content $(\theta)$ and the apparent dielectric constant $\left(K_{a}\right)$, and this method has been widely used.

Since wood is a porous material, TDR methodology could be used to measure its water content. However, a new $K_{a}(\theta)$ specific equation would be needed for wood. Constantz \& Murphy (1990) developed a new equation relating the stem water content to the apparent dielectric constant for Monterey pine (Pinus radiata) with a view to using this methodology to monitor temporal variations in the stem water contents $\left(\theta_{\text {stem }}\right)$ of different tree species. Those authors concluded that this method is rapid and suitable, and that it affords accurate estimates of changes in the moisture stored at a given sampling depth. A single direct relationship between $K_{a}$ and $\theta_{\text {stem }}$ was established. Since then, some authors have used TDR methodology to study stem water content in different species and with different aims (Holbrook \& Sinclair 1992; Wullschleger et al., 1996; Irvine \& Grace, 1997; Kobayashi \& Tanaka, 2001; Sparks et al., 2001; Nadler et al., 2003, 2006).

In all the above works, species-specific equations for the $K_{a}\left(\theta_{\text {stem }}\right)$ relationship were developed. In contrast, Wullschleger et al. (1996) proposed a single, universal calibration equation valid for each species based on four new species and the calibration data used by Constantz \& Murphy (1990). This equation was used in the assays carried out by Nadler et al. $(2003,2006)$ and Nadler (2004) in fruit trees. However, to date, few species have been used and not many studies have been carried out to calibrate and validate TDR methodology for the measurement of wood tissue water content. Moreover, there have been few long-term studies that have compared stem water content under natural conditions with other types of measurements (Constantz \& Murphy, 1990; Wullschleger et al., 1996), such as that of soil moisture, in order to assess the importance of this variable in the water status of the tree. Accordingly, more attention should be devoted to these issues. The aims of this study were as follows:

(a) To develop an equation relating the apparent dielectric constant to the wood water content for the melojo oak (Quercus pyrenaica) and the holm oak (Quercus rotundifolia). We considered that although both species belong to the same genus, the equations would be different because the composition and structure of the wood of both species are different.

(b) To compare the equations determined for these species with those calculated previously. The hypothesis was that more accurate results would be obtained with species-specific equations.

(c) To assess the feasibility of this methodology to detect long-term changes in the stem water content in a forest under sub-humid Mediterranean conditions, and the response of this water stored in the sapwood/heartwood to the soil water deficit.

\section{METHOD}

\section{Calibration of TDR in wood from Quercus pyrenaica Willd. and $Q$. rotundifolia Lam (=subsp. ballota (Desf.) Samp.)}

To analyse the relationship between the dielectric constant and the water content of the melojo oak, a $27 \mathrm{~cm} \mathrm{DBH} \mathrm{(diameter} \mathrm{at} \mathrm{breast} \mathrm{height)} \mathrm{tree} \mathrm{was} \mathrm{cut} \mathrm{down.} \mathrm{A} 100 \mathrm{~cm}$-long segment of the trunk was cut into six samples containing sapwood and heartwood (Fig. 1). Four of them were used for the calibration phase, and two to validate the accuracy of the calibration equation (validation phase). These six segments were rectangular, with a total volume of approximately $1500 \mathrm{~cm}^{3}$. All the bark was removed and a two-rod stainless steel probe (Martínez Fernández \& Ceballos Barbancho, 2001), $12 \mathrm{~cm}$ long and $3 \mathrm{~mm}$ in diameter, was inserted into two parallel predrilled holes in each sample, with a separation of $3 \mathrm{~cm}$ between the rods. Using this configuration, the TDR probe measured the integrated average water content in a volume of wood approximated by a cylinder with a diameter of $3 \mathrm{~cm}, 90 \%$ of the effective volume being $1 \mathrm{~cm}$ away from the 


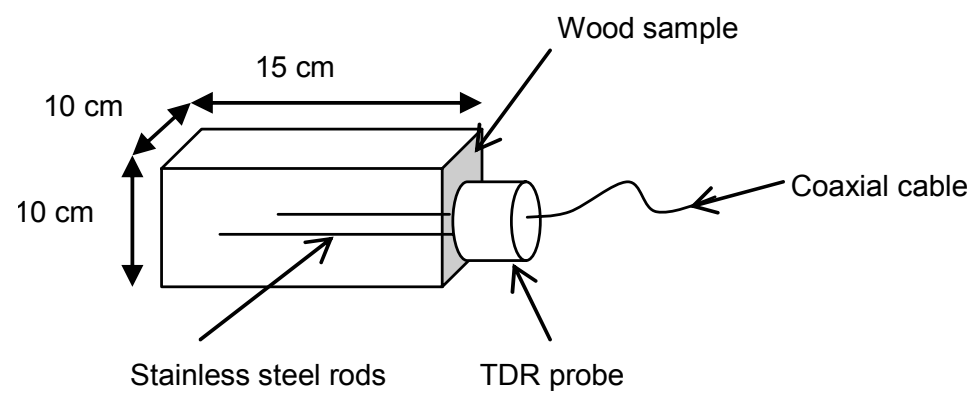

Fig. 1 Schematic drawing of the blocks and TDR probes used in the calibration and reproducibility test.

rods. The guide holes were drilled perpendicular to the vascular system of the block. A rod length of $12 \mathrm{~cm}$ was chosen because previous experience had shown that the resolution of TDR decreases below $10 \mathrm{~cm}$, especially in the case of low water contents, and that probes longer than about $15 \mathrm{~cm}$ are difficult to insert owing to frictional resistance (Constantz \& Murphy, 1990). However, shorter probes $(2 \mathrm{~cm}$ and $5 \mathrm{~cm}$ ) have been used in Scots pine to measure sapwood water contents (Irvine $\&$ Grace, 1997), and $7 \mathrm{~cm}$ rods were used in Citrus limon (Nadler et al., 2003) and Citrus paradise (Nadler, 2004), and in Mangifera indica even shorter ones (Nadler et al., 2006). Irvine \& Grace (1997) reported some sources of errors due to the short length of the probes and the need to minimize the effect of such errors.

After the probes had been inserted into the samples while still in the forest, the blocks were wrapped with paraffin to minimize water loss. They were also stored in a refrigerator to avoid tissue degradation during transportation to the laboratory (approx. 1 hour). The wood blocks were placed on a laboratory bench for saturation for nearly a week. The laboratory bench was filled with water so that the wood would become wet due to capillarity. Over the first four days, the samples were placed horizontally on the bench, with the wood vessels perpendicular to the bottom of the bench. Then, the blocks were oriented vertically for three days, allowing the water to humidify all the wood. Following this, they were air-dried. During this process each block was periodically weighed on a balance with a resolution of $\pm 0.1 \mathrm{~g}$, and its apparent dielectric constant determined. The TDR instrument used was a Tektronix 1502C (Tektronix, Beaverton, Oregon, USA). The time between each measurement varied owing to the block-drying process itself. This time was shorter at the beginning of the process $(12 \mathrm{~h})$, when the blocks were very wet, and was longer (10 days) when the wood was drier at the end of the air-drying process. Before each measurement, each sample was placed in a closed container for $12-48 \mathrm{~h}$ to encourage a more uniform distribution of the moisture within each sample (Constantz \& Murphy, 1990; Holbrook et al., 1992). After more than two months, the samples were nearly dry. To eliminate all the water from the wood tissues, after the probes had been removed the samples were oven-dried at $85^{\circ} \mathrm{C}$ for four days. With these data and those obtained by measuring $K_{a}$, a calibration equation was obtained. To verify the applicability and the accuracy of this equation, two extra samples cut from the same tree, but not used in the calibration phase, were used. The same process as above was applied to these two blocks, and they were also saturated, air-dried, and their weight and $K_{a}$ were determined periodically. Another melojo oak tree was cut down to test the repeatability of the procedure and measurements. The same process described previously was applied to the blocks cut from a segment obtained from the trunk of this tree. The $K_{a}$ of the wood samples used in this reproducibility test was measured with the Tektronix $1502 \mathrm{C}$ and another TDR instrument (TDR100, Campbell Scientific, Inc.) to check whether the different results found in other experiments could be attributed to the use of different devices. The difference between these two devices lies in how the transit time of the electromagnetic pulse is determined. The TDR100 determines $K_{a}$ automatically, thus avoiding the potential error committed by the TDR user. It samples and digitizes the resulting pulse reflection over a specified length of the transmission line. Using the Tektronix $1502 \mathrm{C}$ the reflection is measured manually. This is determined as the 
reflection point of the waveform displayed on the echometer screen, represented by the tangential intersect.

Another calibration equation was calculated for holm oak using the same methodology described above. The shape and dimensions of the blocks were the same as in the previous experiments and the same length of rods was used. In this case, five wood blocks were obtained to determine the $K_{a}(\theta)$ equation and another was used to validate it.

\section{Site description and experimental layout}

The research was conducted at an experimental forested catchment located in the southwest of the Duero basin (Spain). The Rinconada Experimental Catchment (EC) is located $70 \mathrm{~km}$ south of the city of Salamanca, in the western sector of the Sistema Central range. Altitudes range between 1140 and $1450 \mathrm{~m}$ a.m.s.l. with a SW-NE orientation. The climate is sub-humid Mediterranean, with a mean temperature of $10^{\circ} \mathrm{C}$. Mean annual rainfall ranges around $1000 \mathrm{~mm}$, showing considerable interannual variability, with a coefficient of variation (CV) of $26 \%$. November is the wettest month, with $129 \mathrm{~mm}$, and August is the driest, with $15 \mathrm{~mm}$ (Martínez-Fernández et al., 2004). Almost $70 \%$ of the surface of the basin is occupied by melojo oak forest and the basin is used for extensive livestock raising and forestry. Currently, the forest is homogenous, with a high tree density (2300 tree/ha). The soils are mainly leptosols, cambisols and regosols. Their texture is, on average, silt loam. The organic matter content is high (around 10\%) at a depth of $0-15 \mathrm{~cm}$, but is always less than $1 \%$ below a depth of $25 \mathrm{~cm}$. The mean available soil water is $0.094 \mathrm{~cm}^{3} \mathrm{~cm}^{-3}$.

To study the seasonal variations in the stem and soil water contents of the deciduous oak (Quercus pyrenaica), our experimental plots located at the Rinconada EC were selected. Each plot was representative of the different forest stages. The maturity and size of the trees were different, although the differences were not very large. At each plot, four trees representative of the plot were chosen (Table 1). Two different lengths of probe rods were used, 10 and $12 \mathrm{~cm}$, depending on the tree diameters. With these lengths heart and sapwood water content were sampled; however, 10-cm length is the minimum recommended to avoid probe errors (Irvine \& Grace, 1997). The probes were of the two-rod type. Two parallel holes were drilled horizontally into the

Table 1 Basal diameter $(20 \mathrm{~cm})$, diameter at breast height $(\mathrm{DBH}, 120 \mathrm{~cm})$ and height of the trees used in this study.

\begin{tabular}{llllc}
\hline $\begin{array}{l}\text { Experimental } \\
\text { plot }\end{array}$ & Tree no. & $\begin{array}{l}\text { Basal diameter } \\
(\mathrm{cm})\end{array}$ & $\begin{array}{l}\text { DBH } \\
(\mathrm{cm})\end{array}$ & $\begin{array}{l}\text { Height } \\
(\mathrm{m})\end{array}$ \\
\hline \multirow{4}{*}{1} & 1.1 & 20.0 & 15.0 & 9.5 \\
& 1.2 & 21.5 & 17.5 & 11.0 \\
& 1.3 & 19.5 & 15.5 & 9.0 \\
& 1.4 & 22.3 & 18.5 & 10.5 \\
& Mean & 20.8 & 16.6 & 10.0 \\
2 & 2.1 & 24.0 & 20.5 & 12.0 \\
& 2.2 & 17.3 & 13.5 & 15.0 \\
& 2.3 & 19.0 & 15.8 & 10.0 \\
& 2.4 & 24.5 & 17.8 & 10.5 \\
& Mean & 21.2 & 16.9 & 11.9 \\
3 & 3.1 & 25.3 & 18.5 & 12.5 \\
& 3.2 & 18.0 & 14.8 & 10.2 \\
& 3.3 & 26.8 & 18.0 & 14.0 \\
& 3.4 & 21.0 & 15.8 & 12.0 \\
& Mean & 22.8 & 16.8 & 12.2 \\
4 & 4.1 & 21.0 & 15.5 & 9.5 \\
& 4.2 & 20.5 & 14.0 & 9.2 \\
& 4.3 & 22.0 & 14.0 & 10.5 \\
& 4.4 & 18.0 & 13.0 & 11.5 \\
& Mean & 20.4 & 14.1 & 10.2 \\
\hline
\end{tabular}


stems of these 16 trees before insertion at two different heights (DBH: $120 \mathrm{~cm}$ and basal diameter: $20 \mathrm{~cm}$ ) in June 2003. The diameter of each hole was $3 \mathrm{~mm}$ and the separation between holes $3 \mathrm{~cm}$. The two probes were inserted perpendicular to each other and were similarly oriented in all the specimens. Soil moisture was determined in the root zone (up to $50 \mathrm{~cm}$ ) of each tree with two consecutive $25-\mathrm{cm}$ TDR probes inserted vertically into the soil. The densest root system of this species is located in this soil layer, although the trees may also develop a deep tap root (Gómez Manzaneque et al., 1998).

Stem and soil moisture was measured every two weeks, at the same time in the morning, with more frequent measurements in summer, to monitor the seasonal and annual changes in trunk water contents. $K_{a}$ was determined with the same instrument as that used in the calibration process (Tektronix 1502C). Stem water contents were estimated with the equation calculated specifically for this species in the calibration/reproducibility test. Soil moisture was calculated with the equation from Topp et al. (1980).

\section{RESULTS}

\section{Stem water equation for Quercus pyrenaica}

The calibration equation was calculated from four wood samples. The results obtained during the calibration process revealed a good $\left(R^{2}=0.96, p<0.0001\right)$ positive relationship between water contents measured gravimetrically and the $K_{a}$ determined with TDR (Fig. 2). A total of 65 measurements were used. These data were the water contents of the four samples determined during the air-drying process. A third-order polynomial regression equation was fitted to the pooled data, yielding the expression:

$$
\theta=-0.45698+0.11666 K_{a}-0.00416 K_{a}^{2}+0.00005 K_{a}^{3}
$$

where $\theta$ is the volumetric water content $\left(\mathrm{cm}^{3} \mathrm{~cm}^{-3}\right)$ and $K_{a}$ refers to the apparent dielectric constant (dimensionless). Similarly shaped third-order polynomial calibration curves have been reported for water volume in other species (Constantz \& Murphy, 1990; Irvine \& Grace, 1997) and other porous materials such as soil (Topp et al., 1980).

The results obtained in the calibration process were similar to those obtained by Constantz \& Murphy (1990), pioneers in this methodology, and others (Sparks et al., 2001), and better than those obtained in other experiments (Holbrook \& Sinclair 1992; Wullschleger et al., 1996). The water contents of the two blocks obtained from the same tree (used to verify the accuracy of the equation) measured gravimetrically and estimated with this curve were very similar (Fig. 3).

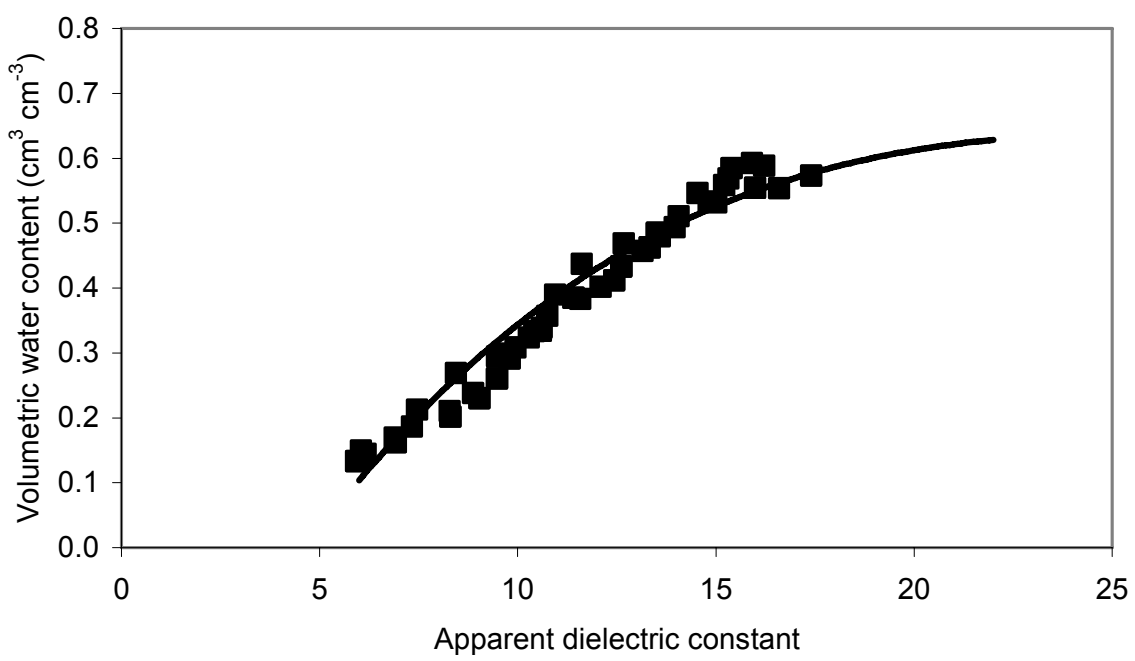

Fig. 2 Relationship between $K_{a}$ and $\theta$ for Quercus pyrenaica and the curve fitted to the calibration data. 


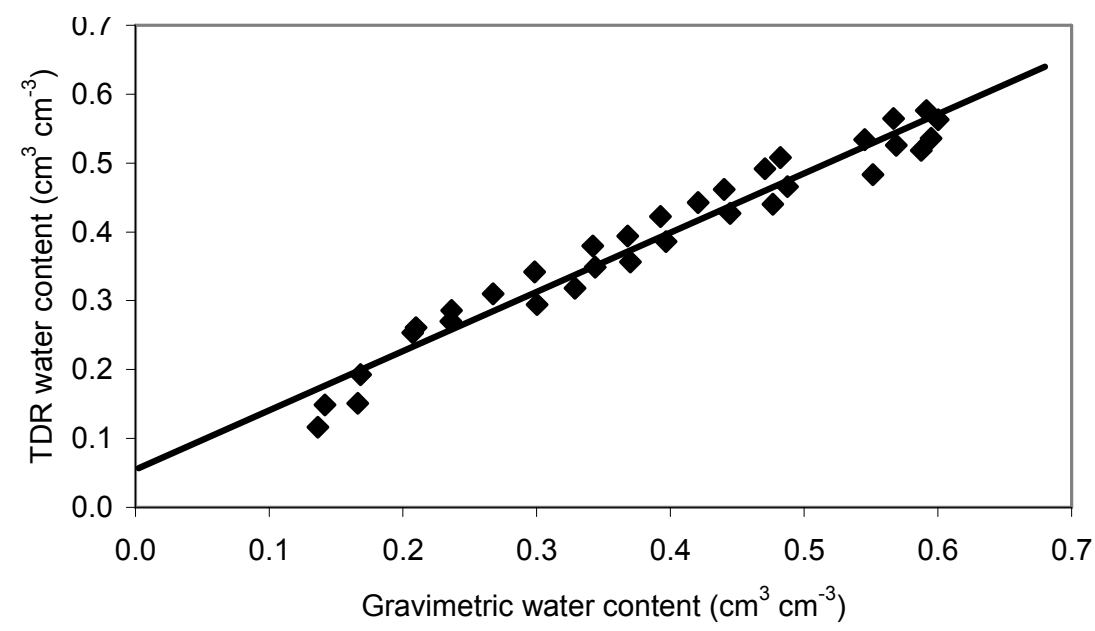

Fig. 3 Comparison of volumetric water contents estimated by TDR and measured gravimetrically in two samples of Quercus pyrenaica.

Table 2 Validation of the calibration equation obtained for Quercus pyrenaica with data from two samples of the first tree and six of the second one, and validation parameters estimated to verify the accuracy of the Quercus rotundifolia curve.

\begin{tabular}{llllcl}
\hline & $\begin{array}{l}\text { No. of } \\
\text { samples }\end{array}$ & $\begin{array}{l}\text { No. of } \\
\text { measurements }\end{array}$ & $R^{2}$ & $\begin{array}{l}\text { Average error } \\
(\%)\end{array}$ & $\begin{array}{l}\text { RMSE } \\
(\%)\end{array}$ \\
\hline Melojo oak 1 & 2 & 33 & 0.96 & -0.37 & 3.02 \\
Melojo oak 2 & 6 & 82 & 0.96 & -6.30 & 6.85 \\
Holm oak & 1 & 10 & 0.94 & 3.31 & 3.68 \\
\hline
\end{tabular}

RMSE: root mean square error.

Comparison $\left(R^{2}=0.96\right)$ of the stem water contents estimated by TDR and those obtained with the gravimetric method confirmed the validity of the procedure used (Table 2). The mean error of each sample (1.6 and $-2.2 \%)$ was low and no significant bias was detected. The root mean square error (RMSE) analysis (3.2 and 3.4\%) was also satisfactory. Although the variability of the data is higher when the results concerning the two melojo trees are compared, the differences appear to be sufficiently small to allow the use of the equation in this species. These differences between the samples have also been detected by other researchers (Constantz \& Murphy, 1990) in their pioneer work, showing that the cause of such variations may be due to natural variations in wood structure and composition among the samples. As possible sources of error, Holbrook et al. (1992) indicated tissue damage, caused by handling and rod insertion, and an uneven distribution of water through the tissue and changes in tissue volume as the wood dries. Water coming out of damaged cells during probe installation remains in the most sensitive place for the TDR, namely, in contact with the rods. This is highly significant for the dielectric constant, but may be negligible relative to the total weight of water mass. Thus, the difference can be explained by at least three factors: higher water content inside the wood sample and lower content outside; seepage from damaged cells; and natural variability. Water was lost (by weight) quite rapidly from the exposed surfaces only on the first day. This period coincides with the greatest differences between both melojo oak individuals. Accordingly, in order to avoid errors derived from such an effect it was decided not to include the data for the highest water volumes in the analysis. Only 4 out of a total of 69 measurements were not considered to calculate the equation for the melojo oak, so that equation would hardly change if all the data were included. The $R^{2}$ was similar (0.94). A similar situation was observed in the case of the holm oak experiment where only six measurements out of a total of 55 were ruled out. Moreover, in the results no dispersion or bias due to incomplete water redistribution was detected. Comparison of the results obtained with the Tektronix 1502C and TDR100 devices in this second reproducibility test revealed good agreement $\left(R^{2}=0.99\right)$ between the two sets of measurements. 
This shows that the results are not dependent on the TDR model used or on potential errors committed by the user with the Tektronix $1502 \mathrm{C}$.

\section{Stem water equation for Quercus rotundifolia}

The relationship between the water content, measured gravimetrically, and $K_{a}$, was not as strong as that found for the melojo oak. However, the determination coefficient $\left(R^{2}=0.89\right)$ and the results obtained in the reproducibility test (Table 2 ) were satisfactory. The regression equation fitted to the pooled data (49) was a third-order polynomial equation (Fig. 4):

$$
\theta=-0.988+0.1791 K_{a}-0.0069 K_{a}^{2}+0.00009 K_{a}^{3}
$$

An extra sample was used to verify the accuracy of this relationship. The parameters estimated to validate the equation were satisfactory (Table 2).

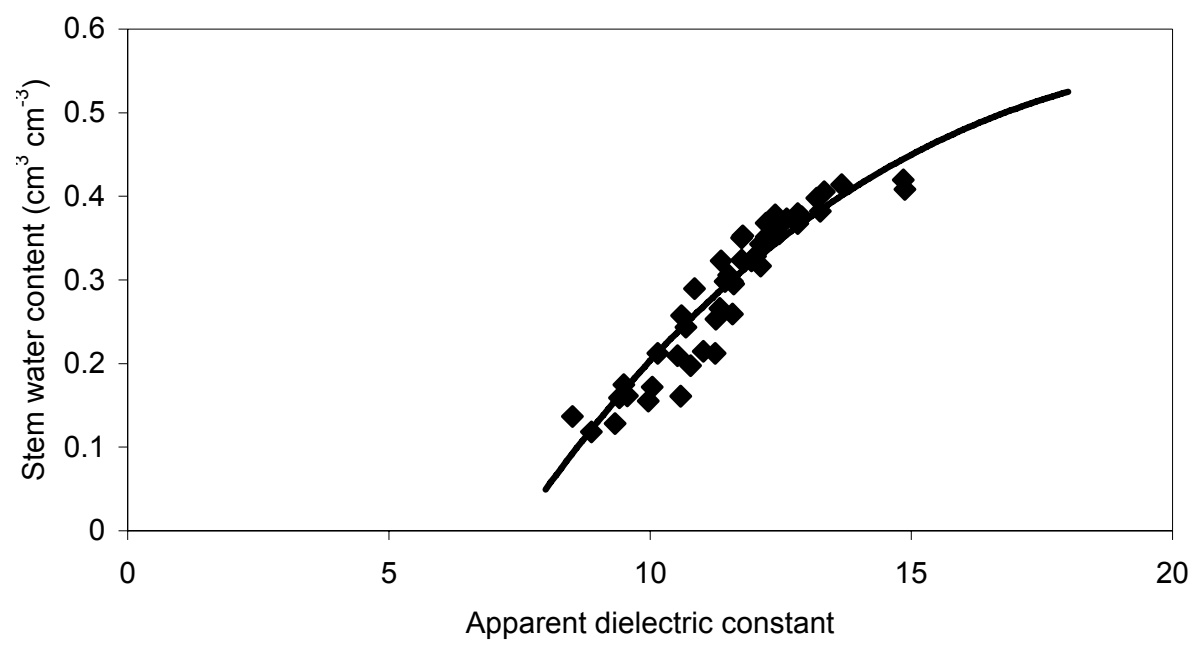

Fig. 4 Relationship between stem water content and the dielectric constant $\left(K_{a}\right)$ for holm oak (Quercus rotundifolia).

\section{DISCUSSION}

\section{Equations for $\boldsymbol{\theta}_{\mathrm{STEM}}-\boldsymbol{K}_{a}$}

The most important result of the present study is that the equations obtained for these species are different from those calculated for other species. The equation proposed by Wullschleger et al. (1996) underestimates the water content of the melojo oak and holm oak, as shown in Fig. 5. Although the equation obtained for the holm oak is more similar to the equation of Wullschleger et al. (1996), it seems to estimate stem water content with less accuracy. To date, the equations published differ from each other. The curve obtained by Constantz \& Murphy (1990) and that of Wullschleger et al. (1996) are more similar to each other than the rest. This may be due to the fact that Wullschleger et al. (1996) combined their data with those of Constantz \& Murphy (1990), because the results for the species studied were also more similar.

To a certain extent, the differences between the equation proposed as universal (Wullschleger et al., 1996) and the curves obtained here for two oak species can be accounted for in the sense that the methodologies used were slightly different. First, in our experiments, the bark of the wood blocks was removed, as was the case in the work by Constantz \& Murphy (1990). However, Wullschleger et al. (1996) used logs that still had the bark attached. Another difference is that before the measurements were taken by us, and others, the wood samples were placed in a closed container to encourage a more uniform water distribution within each sample (Constantz \& Murphy, 1990; Holbrook et al., 1992; Irvine \& Grace, 1997). In contrast, the measurements taken 


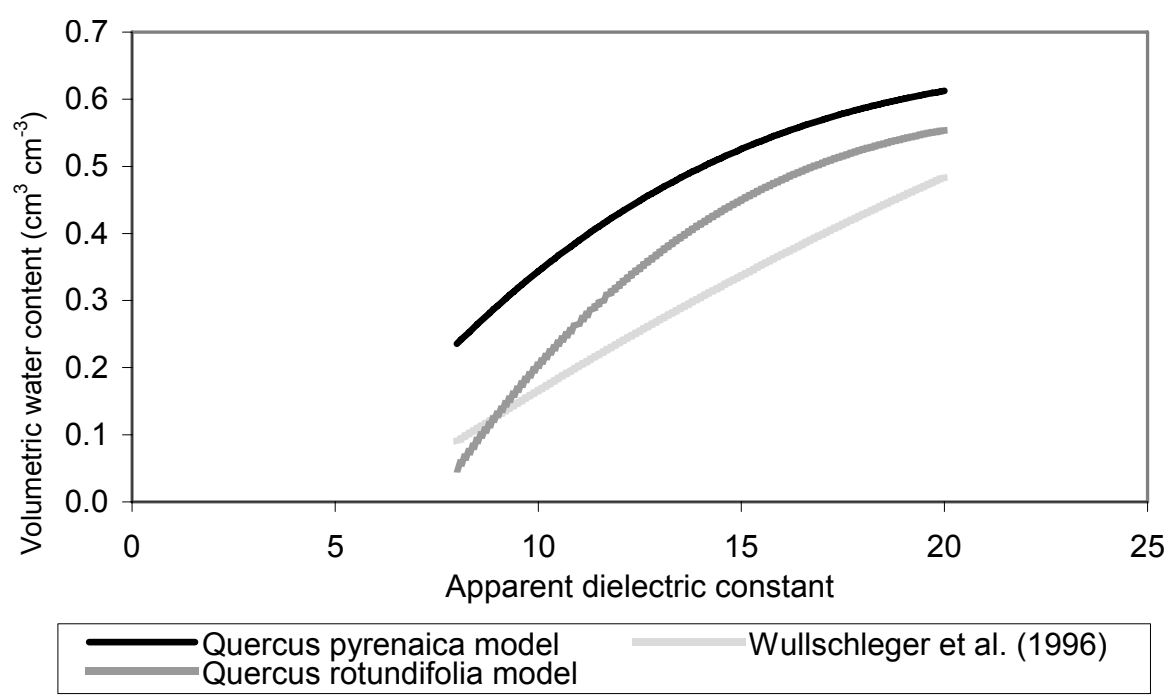

Fig. 5 Comparison between the equations calculated for Quercus pyrenaica, Quercus rotundifolia and that estimated by Wullschleger et al. (1996).

by Wullschleger et al. (1996) were obtained without enclosing the samples in closed containers. Although the wood samples used by Wullschleger et al. (1996) were small, and the differences should therefore also be small, owing to a possible non-uniform distribution of water within the $\log$ at the time of each measurement, the $K_{a}$ measured at the placement of the probe might not have been representative of the water content of the entire log. Finally, in the case of Wullschleger et al. (1996) the samples were not saturated before they were allowed to dry. Some differences with other experiments carried out previously could be explained as follows. In some studies only the sapwood was used to calculate the calibration curve (Constantz \& Murphy, 1990; Irvine \& Grace, 1997; Sparks et al., 2001). In the present work, the samples contained sapwood and heartwood because in the study carried out in living trees the water content of both types of wood tissue was measured. Probe length may have influenced the differences found with the equations estimated for Pinus sylvestris (Irvine \& Grace, 1997). Finally, the main explanation for the differences among the various equations could be related to natural variations in wood structure and composition among species.

\section{Measuring stem water content in living trees}

Measurements of stem water contents were begun in June 2003. However, the summer months of 2003 were not included in the analysis because probe insertion could have elicited measurement errors. After that time and the recovery of stem water content due to the autumn rainfall when soil became recharged, the error was assumed to be negligible. In the case of felled tree segments, we did not wait to take the water content measurements of the blocks because they were hydrated artificially in the laboratory. If we had waited the same time as for the living trees, the samples would have become useless for our purpose. As shown in Fig. 6, the average stem water contents of 16 oaks corresponded to the soil water content, except for the winter months, when the correlation between the two variables was not so clear. This weak relationship can be explained in terms of the strong effect of winter freezing on TDR measurements (Constantz \& Murphy, 1990; Sparks et al., 2001). In the winter of 2003/04 absolute minimum temperatures of $-5^{\circ} \mathrm{C}$ were registered in the study area. In addition, this weak relationship can be explained because soil wetting (due to rain) is usually much faster than its drying, while in trees the rates of emptying and refilling of stem storage are quite similar. Considering the data only from 2004 to have a whole seasonal period, stem water measurements in living Quercus pyrenaica individuals exhibited a maximum variation of $17 \%$, the maximum soil moisture variation being about $60 \%$. Regarding the temporal differences recorded by the two probes in each tree, the maximum variation for the lower 


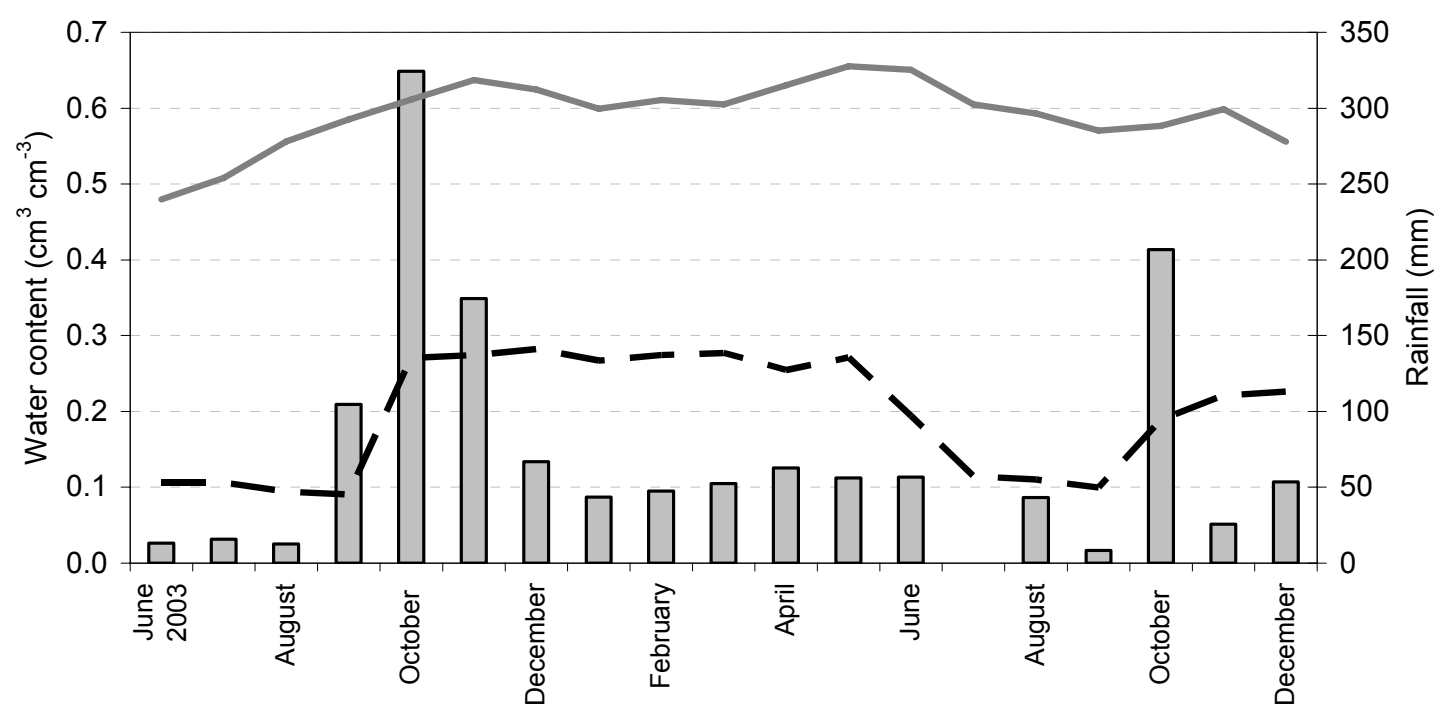

Rainfall $\longrightarrow$ Q. pyrenaica stem water content - - Soil moisture

Fig. 6 Temporal evolution of the stem water content averaged from the 16 melojo oaks (Quercus pyrenaica) measured, averaged soil moisture in the root zone and monthly rainfall. A lag between the soil moisture content rise due to autumn rainfall and stem water content may be observed, produced by the quicker response of soil moisture to rainfall, and the lower effect of soil moisture in stem water content. The maximum stem water content occurs when soil water content has already started to decrease, due to the increase in water absorption by trees associated with new leaf growth and no soil moisture deficit yet. In the analysis the data from June to October were not considered to avoid possible errors derived from probe installation.

probe was $28 \%$ and the minimum $14 \%$, while the values for the other probe were 28 and $20 \%$, respectively. A similar variation was found in another two oak species: $16 \%$ in white oak (Q. alba), and $19 \%$ in chestnut oak (Q. prinus) (Wullschleger et al., 1996). The stem water content averaged for the 16 trees increased from March to May/June. The maximum value was reached in May $(0.656$ $\left.\mathrm{cm}^{3} \mathrm{~cm}^{-3}\right)$, associated with new leaf growth and no soil moisture deficit $\left(0.271 \mathrm{~cm}^{3} \mathrm{~cm}^{-3}\right)$. The absolute maximum for the trees varied between 0.618 and $0.665 \mathrm{~cm}^{3} \mathrm{~cm}^{-3}$ for the probe at $120 \mathrm{~cm}$ and between 0.656 and $0.678 \mathrm{~cm}^{3} \mathrm{~cm}^{-3}$ for that at $20 \mathrm{~cm}$. Thus, the stem water volume decreased gradually throughout the summer in parallel with the soil moisture content. The minimum value, $0.570 \mathrm{~cm}^{3} \mathrm{~cm}^{-3}$, was reached in September 2004, when the soil water content was the lowest due to the end of the hot, dry season $\left(0.099 \mathrm{~cm}^{3} \mathrm{~cm}^{-3}\right)$. The minimum range attained by each tree in absolute terms was $0.509-0.490 \mathrm{~cm}^{3} \mathrm{~cm}^{-3}$ for the probe inserted higher in the trunk and $0.541-$ $0.583 \mathrm{~cm}^{3} \mathrm{~cm}^{-3}$ for the one located lower down. Once the soil had been recharged by the autumn rainfall, the stem was partially recharged. This water movement into and out of storage in the sapwood/heartwood could be used as a tree water store to meet transpiration needs (Waring \& Running, 1978; Kobayashi \& Tanaka, 2001).

A correlation analysis was performed with the complete database between stem water and soil-root zone moisture content. Despite the positive relationship, the correlation was statistically significant, but low $(R=0.52)$, for the reasons mentioned above. To gain deeper insight into this issue, the same analysis was carried out with only the measurements from the entire May-October 2004 period (growing season). During these months a marked soil water deficit was detected, due to rainfall interception, rainfall scarcity, and an increase in evaporation and in water uptake by trees. These months also constitute the most interesting period because they coincide with the vegetative period of this species under Mediterranean conditions. In these terms, the relationship is much stronger $(R=0.84)$. A regression analysis was carried out considering soil moisture as the independent variable and the stem water content as the dependent one (Fig. 7), providing a $R^{2}$ value of 0.89 . These results show the strong relationship between the water storage of the soil and 


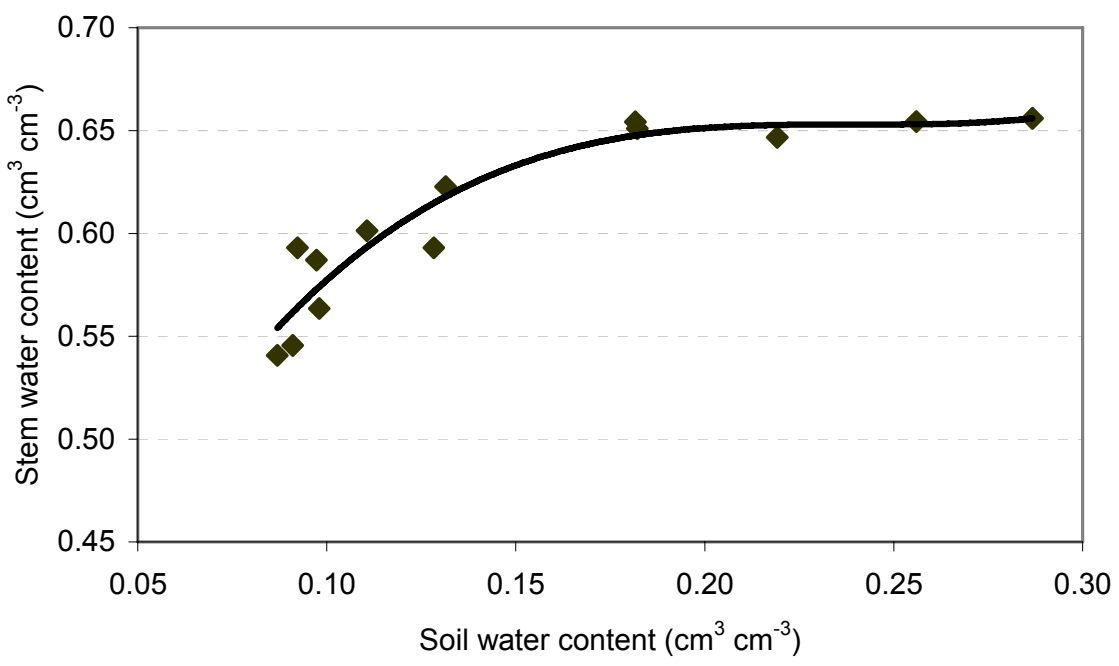

Fig. 7 Third order polynomial equation fitted to the data measured in May-October $2004(N=13)$.

stem. The percentage not explained by this relationship could be related to evaporated soil water or to water that had drained below the depth monitored, and hence not taken up by the stem. Moreover, it can be seen that for soil moisture measurements higher than about $0.18 \mathrm{~cm}^{3} \mathrm{~cm}^{-3}$, the stem water content remained almost the same. For a soil moisture variation of $36 \%$, the water measured in the trunk varied less than $1 \%$. Under wet conditions, the water used by the leaves from stem storage is almost immediately replenished, creating a situation where water flows from the soil to the stem with only small losses in the stem. However, for values lower than $0.18 \mathrm{~cm}^{3} \mathrm{~cm}^{-3}$, the same difference in soil water content (36\%) leads the water storage of the tree to decrease by about $8 \%$. Under low soil water content conditions, a larger fraction of the total stem water content is used, with only minute changes in soil water content, and even these are at the edges of the root zone and are not easy to detect.

\section{CONCLUSIONS}

Two different equations were obtained for each of the oak species studied in this work; these differ from those calculated for other species. Accordingly, more accurate results could be obtained when using species-specific equations. Considering all the results from the different studies carried out to date, it is recommended that, although the curve shape is similar in different tree types, the earlier claim that the original calibration of Wullschleger et al. (1996) could be used as universal reference should be considered with caution. Although it would be very useful to obtain a single equation to estimate the stem water content of trees, it is still necessary to know the results for many more species. Owing to the potential of the technique described here to monitor stem water variation, more work should be carried out in the future to determine the variables of wood that may influence TDR measurements and discover whether a universal equation is possible or whether species-specific curves should be used.

The results of measuring stem water content in the melojo oak show that it is possible to monitor the stem water content of this species, and use it as an indicator of soil-tree water relationships in response to long-term water stress in order to study the effects of the environment on plant water status. Further studies should be conducted in order to gain deeper insight into the role of water movement to and from this storage pool which, as can be derived from our results, can be measured satisfactorily with this technique.

The use of this technique could help to measure water stores in tree trunks, as well as their spatial and temporal evolution. Thus, the water storage capacity and temporal changes in xylem water content could be better understood, as well as the role of stem water content and its 
importance in maintaining transpiration in dry episodes. Knowledge of the stem water content could also shed some light on the observed time lags in some tree species between sapflow measured at the base and the upper part of the trunks (Granier et al., 1996; Köstner et al., 1996; Phillips et al., 2003). These differences are the result of changes in water storage within the trees. Finally, TDR offers opportunities to obtain precise water balance calculations for forested watersheds and accurately estimate tree water stress, both of interest to tree physiologists, forest hydrologists, modellers, etc.

Acknowledgements This study was fully supported by the Spanish Ministry of Science and Technology (Project REN2003-00381) and the Spanish Ministry of Environment (Project RESEL). The authors would like to thank Dr A. Nadler and one anonymous referee for their useful comments on the manuscript and Carlos Morán and Ana Cano for assistance in the fieldwork and laboratory.

\section{REFERENCES}

Braekke, F. H. \& Kozlowski, T. T. (1975) Shrinkage and swelling of stems of Pinus resinosa and Betula papyrifera in northern Wisconsin. Plant \& Soil 43, 387-410.

Brough, D. W., Jones, H. G. \& Grace, J. (1986) Diurnal changes in water content of the stems of apple trees, as influenced by irrigation. Plant Cell Environ. 9, 1-7.

Byrne, G. F., Fenn, M. N. \& Burgar, M. I. (1986) Nuclear magnetic resonance studies of water in tree sections. Agric. For. Met. 38, 307-317.

Constantz, J. \& Murphy, F. (1990) Monitoring storage moisture in tree using time domain reflectometry. J. Hydrol. 119, $31-42$.

Edwards, W. R. N. \& Jarvis, P. G. (1983) A method for measuring radial differences in water content of intact tree stems by attenuation of gamma radiation. Plant Cell Environ. 6, 255-260.

Gómez Manzaneque, F., Moreno Saiz, J. C., Morla Juaristi, C., Regato Pajares, P. \& Sainz Ollero, H. (1998) Bosques ibéricos: una interpretación geobotánica. Planeta, Barcelona, Spain.

Granier, A., Biron, P., Köstner, B., Gat, L. W. \& Najjar, G. (1996) Comparisons of xylem sap flow and water vapour flux at the stand level and derivation of canopy conductance for Scots pine. Theoret. Appl. Clim. 53, 115-122.

Holbrook, N. M. \& Sinclair, T. R. (1992) Water balance in the arborescent palm, Sabal palmetto, II. Transpiration and water storage. Plant Cell Environ. 15, 401-409.

Holbrook, N. M., Burns, M. J. \& Sinclair, T. R. (1992) Frequency and time domain dielectric measurements of stem water content in the arborescent palm, Sabal palmetto. J. Exper. Bot. 43, 111-119.

Irvine, J. \& Grace, J. (1997) Non destructive measurement of stem water content by time domain reflectometry using short probes. J. Exper. Bot. 48, 813-818.

Kobayashi, Y. \& Tanaka, T. (2001) Water flow and hydraulic characteristics of Japanese red pine and oak trees. Hydrol. Processes 15, 1731-1750.

Köstner, B., Biron, P., Siegwolf, R. \& Granier, A. (1996) Estimates of water vapor flux and canopy conductance of Scots pine at tree level utilizing different xylem sap flow methods. Theoret. Appl. Clim. 53, 105-113.

Martínez Fernández, J. \& Ceballos Barbancho, A. (2001) Diseño y validación de una sonda TDR para la medición de la humedad del suelo. In: Temas de investigación en zona no saturada (ed. by J. J. López \& M. Quemada), 37-47. Universidad Pública de Navarra, Pamplona, Spain.

Martínez-Fernández, J., Ceballos, A., Morán, C., Hernández, V. \& Casado, S. (2004) Hydrological processes along a Mediterranean rainfall gradient. In: Progress in Surface and Subsurface Water Studies at the Plot and Small Basin Scale (ed. by D. Tropeano, M. Arattano, F. Maraga \& C. Pelissero), 163-166. Consiglio Nazionale delle Ricerche-Instituto di Ricerca per la Protezione Idrogeologica. Torino, Italy.

Nadler, A. (2004) Relations between soil and tree stem water content and bulk electrical conductivity under salinizing irrigation. Soil Sci. Soc. Am. J. 68, 779-783.

Nadler, A. (2006) Stress induced water content variations in mango stem by time domain reflectometry. Soil Sci. Soc. Am. J. 70. $510-520$.

Nadler, A., Raveh, E., Yermiyahu, U. \& Green, S. R. (2003) Evaluation of TDR use to monitor water content in stem of lemon trees and soil and their response to water stress. Soil Sci. Soc. Am. J. 67, 437-488.

Phillips, N. G., Ryan, M. G., Bond, B. J., McDowell, N. G., Hinckley, T. M. \& Cérmak, J. (2003) Reliance on stored water increases with tree size in three species in the Pacific Northwest. Tree Physiol. 23, 237-245.

Raschi, A., Tognetti, R., Ridder, H. W. \& Béres, C. (1995) Water in the stems of sessile oak (Quercus petraea) assessed by computer tomography with concurrent measurements of sap velocity and ultrasound emission. Plant Cell Environ. 18, 545-554.

Sparks, J. P., Campbell, G. S. \& Black, R. A. (2001) Water content, hydraulic conductivity, and ice formation in winter status of Pinus contorta, a TDR case study. Oecologia 127, 468-475.

Topp, G. C., Davis, J. L. \& Anan, A. P. (1980) Electromagnetic determination of soil water content, measurements in coaxial transmission lines. Water Resour. Res. 16, 574-582.

Waring, R. H. \& Running, S. W. (1978) Sapwood water storage, its contribution to transpiration and effect upon water conductance through the stems of old-growth Douglas fir. Plant Cell Environ. 1, 131-140.

Wullschleger, S. D., Hanson, P. J. \& Todd, D. E. (1996) Measuring stem water content in four deciduous hardwood with a time domain reflectometry. Tree Physiol. 16, 809-815. 